\title{
Evaluation of the Therapeutic Effect of Radioattenuated Yeast Cells in Experimental Paracoccidioidomycosis
}

Estefania Mara do Nascimento Martins ${ }^{1^{\star}}$, Viviane Cristina Fernandes ${ }^{2}$, Elis Araújo Morais ${ }^{2}$, Jankerle N. Boeloni4, Maria Aparecida de Resende ${ }^{1}$, Alfredo Miranda Goes $^{2}$ and Antero Silva Ribeiro de Andrade ${ }^{3}$

${ }^{1}$ Departament of Microbiology, Institute of Biological Sciences, Federal University of Minas Gerais (UFMG), caixa postal 486, Belo Horizonte, MG 31270-901, Brasil

2 Department of Biochemistry and Immunology, Institute of Biological Sciences, Federal University of Minas Gerais (UFMG), caixa postal 486, Belo Horizonte, MG 31270-901, Brasil

Laboratory of Radiobiology, Center of Nuclear Technology Development (CTDN), caixa postal 941, Belo Horizonte, MG 30123-970, Brasil

${ }^{4}$ Department of Veterinary Clinic and Surgery, Veterinary School, Federal University of Minas Gerais (UFMG), caixa postal 486, Belo Horizonte, MG 31270-901, Brazil

*Corresponding author: Estefania Mara do Nascimento Martins, Departament of Microbiology, Institute of Biological Sciences, Federal University of Minas Gerais (UFMG), caixa postal 486, Belo Horizonte, MG 31270-901, Brasil, Tel: +55 313409 2632; Fax: +55 31 3409 2614; E-mail: estefaniamartinsbio@gmail.com

Received date: 01 July 2014; Accepted date: 21 Aug 2014; Published date: 25 Aug 2014

Copyright: (c) 2014 Nascimento Martins EMD, et al. This is an open-access article distributed under the terms of the Creative Commons Attribution License, which permits unrestricted use, distribution, and reproduction in any medium, provided the original author and source are credited.

\begin{abstract}
Paracoccidioides brasiliensis is the agent of paracoccidioidomycosis (PCM), the most prevalent deep mycosis in Latin America. The treatment varies according to the chemotherapeutic drug and the disease severity, and the lack of it can results in high frequency of relapse and sequels. Thus, the search for new therapeutic alternatives is necessary. The aim of this study was to evaluate the therapeutic effect of $P$. brasiliensis yeast cells attenuated by gamma irradiation (LevRad) in Balb/c mice. Mice immunized with LevRad and/or treated with fluconazole presented a significant decrease in the CFU recovery from the lung, liver and spleen in comparison with non-immunized and non-treated infected mice (60 and 120 days after infection). After 120 days from fungal inoculation, no fungi colonies were obtained from the organs of treated and immunized mice. The tissue structure of these organs was largely preserved. At the same time, anti-Mexo specific IgG antibodies levels and TGF- $\beta$, IFN- $\gamma$, iNOS transcript levels were high and a decrease on the IL-4, IL-10 and TNF- $\alpha$ transcript levels was also verified. An additive protective effect of immunization with LevRad associated to chemotherapy in a PCM experimental model was verified, providing evidence of the therapeutic effect of attenuated yeast for fungal infections.
\end{abstract}

Keywords: Therapeutic vaccine; Paracoccidioides brasiliensis; Gamma irradiation; Paracoccidioidomycosis

\begin{abstract}
Abbreviations:
PCM: Paracoccidioidomycosis, Pb18: Paracoccidioides brasiliensis strain; LevRad: $P$. brasiliensis yeast cells attenuated by gamma irradiation; CETEA: Ethics Committee in Animal Experimentation of the Federal University of Minas Gerais; CFU: Colony Forming Units; TMB: Tetramethylbenzidine
\end{abstract}

\section{Introduction}

The most prevalent deep mycosis in Latin America, Paracoccidioidomycosis (PCM), is caused by the thermally dimorphic fungus Paracoccidioides brasiliensis. It is estimated that approximately 10 million people are infected, although most of them are asymptomatic [1]. A total of 3181 lethal PCM cases were registered in Brazil between the years 1980 and 1995 . However, it is plausible to believe that this number is still underestimated, since the disease is not indicated for mandatory reporting [2].

PCM may manifest in two distinct forms: the chronic (adults) and the acute/subacute (adults and juveniles). The acute form affects the reticule-endothelial system and it may be fatal, whereas the chronic form often causes lesions in the lungs with consequent dissemination to other organs and tissues. Such damage may result in severe restriction of respiratory function. This medical situation might have negative effects on the patients' working performance, which strongly affects their life quality with significant social and economic factors $[3,4]$.

The therapy for PCM consists on the use sulfonamides, polyenes (amphotericin B) and azoles derivates. The lack of treatment is usually fatal [5]. Normally, the therapy consists in a long-term treatment, which may last from 2 to 6 months. However, long term drug administration enhances the chances of treatment failure due to occasional interruption by the patient. Such interruption may increase the frequency of reactivation of quiescent focus. Therefore, developing new and more effective chemotherapeutic strategies are of great importance to better the immune protective response and to help controlling the disease [6,7].

There are some reports describing the role of antigens inducing immune responses against $P$. brasiliensis such as soluble antigen, purified antigen, peptide, DNA vaccine and the use of attenuated yeast cells [8-22].

Live-attenuated pathogens have been used successfully as vaccine candidates against various viral and bacterial pathogens [23]. There is no fungal vaccine available at present. Our group have been investigated the potential of $P$. brasiliensis yeast cells attenuated by gamma irradiation (LevRad) to induce protection against a $P$. brasiliensis infection. The endovenous immunization of Balb/c mice with the radioattenuated yeast cells (without the use of adjuvant), was able to elicit a potent and durable protection against infective highly yeasts of $P$. brasiliensis $[17,18]$. 
A main concern with live-attenuated vaccines is the risk of virulence reversion. However, gamma irradiation seems to have been a viable strategy to attenuate microorganism since alterations in the nucleus and an extensive DNA fragmentation were observed [16]. Furthermore, the loss of infectivity was confirmed in immunocompetent Balb/c mice [18] as well as in immunosuppressed mice as will be shown in this work.

In this study, the immunotherapeutic potential of LevRad, in association or not with fluconazole was tested to assess the concept that radioattenuated yeast could be a useful therapeutic tool for PCM or other fungal diseases of medical and veterinary relevance.

\section{Materials and Methods}

\section{Animals}

This work was approved by the Ethics Committee in Animal Experimentation of the Federal University of Minas Gerais (CETEA/ UFMG), protocol 132/2006. Male Balb/c mice (6-8 weeks old) were purchased from UFMG (Belo Horizonte, MG, Brazil) and maintained under specific-pathogen-free conditions as previously described [24]. $\mathrm{Balb} / \mathrm{c}$ mice were immunodepressed by gamma irradiation $\left(\mathrm{Balb} / \mathrm{c}^{\star}\right)$ using uniform doses of $2.5 \mathrm{~Gy}$ (Gray) from a uniform source of 60Co gamma rays. Athymic mice (Nude), 5-8 weeks old, were kindly provided by Professor Leda Quercia Vieira from the Biologic Science Institute at the Federal University of Minas Gerais (ICB/UFMG).

\section{P. brasiliensis strain}

P. brasiliensis yeast cells ( $\mathrm{Pb} 18)$ were maintained in YPD agar medium $(0.5 \%$ yeast extract, $0.5 \%$ peptone, $1.5 \% \mathrm{D}$-glucose, $1.5 \%$ agar, $\mathrm{pH} 7.0)$ at $35^{\circ} \mathrm{C}$ and used after seven days of incubation. The viability of fungal suspensions was determined by staining according to Janus Green B vital dye method (Merck, Rahway, New Jersey) [25]. The viability was always higher than $90 \%$. The virulence of the $\mathrm{Pb} 18$ isolate was verified by intratracheal infection of $\mathrm{Balb} / \mathrm{c}$ mice and further recovering of yeast cells from their organs.

\section{P. brasiliensis attenuation}

Cultures of $P$. brasiliensis yeast cells (Pb18), incubated in YPD agar medium were irradiated in the presence of oxygen and at room temperature. The irradiation was performed in a uniform source of $60 \mathrm{Co}$ gamma rays at dose rate of $1000 \mathrm{~Gy} / \mathrm{h}$. A dose of $6.5 \mathrm{kGy}$ was used to achieve attenuation as in Demichelli and colleagues [16]. The viability of irradiated fungal suspensions was determined by Janus Green B vital dye method [25] (Merck, Rahway, New Jersey). Radioattenuated $P$. brasiliensis viable yeast cells were named LevRad.

\section{Evaluating of LevRad infectivity}

The LevRad infectivity loss was evaluated on athymic (Nude), immunodepressed $\left(\mathrm{Balb} / \mathrm{c}^{\star}\right)$ and normal $(\mathrm{Balb} / \mathrm{c})$ mice. They were inoculated by intratracheal or endovenous route $\left(1 \times 10^{7}\right.$ viable yeast cells of LevRad). After 30 and 90 days their organs were collected for the recovery of colony forming units (CFU) and histopathological changes. Uninfected animal (C-) and infected with non-irradiated virulent yeast cells of $P$. brasiliensis $(\mathrm{C}+)$ were used as control.

\section{Therapeutic vaccination experimental design}

Male Balb/c mice were distributed in five groups (with 5 animals each): uninfected (C-), infected with non-irradiated virulent yeast cells of $P$. brasiliensis $(\mathrm{C}+)$, infected and treated with fluconazole (InMed), infected and immunized with LevRad (InRad) and infected and treated with fluconazole associated with LevRad (InRadMed).

The animals were infected 1 with viable non-irradiated virulent yeast cells of $P$. brasiliensis ( $\mathrm{Pb} 18$ ). Thirty days after infection, mice were immunized with LevRad or treated with fluconazole associated or not with LevRad. After that, the animals were euthanized 60 and 120 days after infection (30 and 90 days after the beginning of the treatment) and their organs were removed to isolate the colonyforming units (CFU) 4, observe histopathological changes5, and quantify iNOS enzyme and cytokine (IFN- $\gamma$, IL-4, IL-10, TNF- $\alpha$ and TGF- $\beta$ ) transcript levels6. Sera were collected just before infection (P0) and after infection, at 30 (P30), 60 (P60) and 120 (P120) days. This procedure was performed to evaluate the immunization effectiveness through total IgG levels7. IgG1, IgG2a, IgG2b and IgG3 levels were also tested 60 and 120 days after infection8.

\section{Mice intratracheal infection}

Male Balb/c mice were previously anesthetized by intramuscular (i.m) injection with $40 \mu \mathrm{L}$ of a solution containing $57 \%$ of ketamine at $80 \mathrm{mg} / \mathrm{Kg}$ (Dopalen, Vetbrands, Brazil) and $43 \%$ of xylazine at 15 $\mathrm{mg} / \mathrm{Kg}$ (Dopaser, Laboratório Calier do Brasil LTDA, Brazil). After anesthesia, their necks were hyper-extended. A suspension of $3 \times 10^{5}$ viable yeast cells of virulent $P$. brasiliensis ( $\mathrm{Pb} 18$ ), in $50 \mu \mathrm{L}$ of sterile phosphate-buffered saline solution (PBS, $\mathrm{pH}$ 7.2), was injected with a 30 -gauge needle into the exposed trachea. The incisions were sutured with 4-0 silk.

\section{Infected mice immunized with LevRad}

After 30 days of infection, Balb/c mice were immunized twice (at 2 week intervals), by the ocular plexus with the injection of 105 radioattenuated yeast cells in $50 \mu \mathrm{L}$ of sterile PBS, without adjuvant.

\section{Chemotherapy of infected mice}

After 30 days of infection, Balb/c mice were treated intraperitoneally (for 30 days) with daily fluconazole doses at 10 $\mathrm{mg} / \mathrm{Kg}$ (Mantena laboratories Hyderabad, India).

\section{CFU recovery in organs of infected mice immunized with LevRad and/or treated with fluconazole}

CFU were isolated at 60 and 120 days after infection from the lungs, spleens and livers. The organs were removed, weighed, homogenized in PBS pH 7.2 and plated on solid brain heart infusion medium (BHI agar) (BHI, Difco Laboratories, Detroit, MI, USA) supplemented with $4 \%$ fetal calf serum and 5\% P. brasiliensis spent culture medium (Pb18) as growth factor. Gentamycin was added at $40 \mathrm{mg} / \mathrm{l}$. The plates were incubated at $35^{\circ} \mathrm{C}$ and $\mathrm{CFU}$ were counted after 20 days. The results were expressed as the number of $\log 10 \mathrm{CFU}$ of viable yeast cells of $P$. brasiliensis per gram of tissue per mouse in each experimental group. 
Citation: Nascimento Martins EMD, Fernandes VC, Morais EA, Boeloni JN, Resende AD, et al. (2014) Evaluation of the Therapeutic Effect of Radioattenuated Yeast Cells in Experimental Paracoccidioidomycosis. J Vaccines Vaccin 5: 248. doi:10.4172/2157-7560.1000248

Page 3 of 9

\section{Histopathology}

Balb/c mice were euthanized 60 and 120 days after infection. The lung, spleen and liver were excised, fixed in $10 \%$ buffered formalin, and embedded in paraffin for sectioning. The sections were stained with hematoxylin \& eosin ( $\mathrm{H} \& \mathrm{E})$ to characterize the inflammatory response or Grocott's methenamine-silver nitrate (Grocott) for identification of fungi and examined microscopically.

\section{iNOS enzyme and cytokines transcript levels}

Real-time PCR assays were performed to quantify iNOS enzyme and cytokines transcripts levels in the lung from intratracheally infected mice submitted to the immunization with LevRad associated or not with fluconazole. The lungs were then excised from mice, mixed with Trizol LS Reagent (Invitrogen, Carlsbad, CA) and frozen at $-70^{\circ} \mathrm{C}$. Total RNA was extracted according to the manufacturer's instructions. Isolated RNA was incubated with $1 \mathrm{U} / \mu \mathrm{g}$ RNA of RNAse free DNAse (Promega, São Paulo, SP, Brazil) for $30 \mathrm{~min}$ at $37^{\circ} \mathrm{C}$. The samples were then purified with phenol-chloroform extraction followed by an ethanol precipitation (Sigma, St. Louis, MO, USA) and reverse transcription with RevertAid ${ }^{\mathrm{m}} \mathrm{H}$ Minus First Strand cDNA Synthesis Kit (Fermentas Molecular Biology Products, Pittsburgh PA, USA). Real-time quantitative PCR was carried out with $10 \mu \mathrm{l}$ of SYBR green PCR master mix (Applied Biosystems, São Paulo, SP, Brazil), 4.0 $\mu \mathrm{l}$ of cDNA, and primers at a final concentration of 5 pmol, in a final volume of $20 \mu$ l. Primers of IL-4, IL-10, TNF- $\alpha$, TGF- $\beta$, IFN- $\gamma$ and iNOS were designed according to Giulietti and colleagues [26] using the Primer Express ${ }^{\circledast}$ software v2.0 (Applied Biosystems, São Paulo, SP, Brazil). Samples were first submitted to the temperatures of $50^{\circ} \mathrm{C}$ for 2 min and $60^{\circ} \mathrm{C}$ for $1 \mathrm{~min}$ and then subjected to 45 cycles of amplification $\left(95^{\circ} \mathrm{C}\right.$ for $15 \mathrm{~s}$ followed by $60^{\circ} \mathrm{C}$ for $\left.1.0 \mathrm{~min}\right)$ using an ABI PRISM 7900 apparatus (Applied Biosystems, São Paulo, SP, Brazil). Dissociation curves occurred at $95^{\circ} \mathrm{C}$ for $15 \mathrm{~s}$ and $60^{\circ} \mathrm{C}$ for 15 s. All quantifications were normalized to the beta-actin housekeeping gene. A nontemplate control with no genetic material was included to verify contamination. Cytokines and iNOS enzyme transcripts levels were assessed through the comparative Ct method, using uninfected mice as the calibrator and reporter. A 2 fold increase was determined as the baseline to differentiate the gene expressed from the calibrator.

\section{Antibody response to LevRad}

ELISA MaxisorbTM surface plates (NUNCTM Brand Products, Roskilde, Denmark) were coated overnight at $4^{\circ} \mathrm{C}$ with $0.5 \mu$ g per well of $P$. brasiliensis exoantigen (Mexo) [27] in carbonate/bicarbonate buffer, $\mathrm{pH}$ 9.6. Wells were blocked for $1 \mathrm{~h}$ at $37^{\circ} \mathrm{C}$ with $1.6 \%$ casein PBS solution, $\mathrm{pH}$ 7.2. The sera were collected just before (P0), as well as at 30 (P30), 60 (P60) and 120 (P120) days after infection. After that they were incubated at dilution 1:100 in $0.25 \%$ casein PBS solution, $\mathrm{pH} 7.2$ for $1 \mathrm{~h}$ at $37^{\circ} \mathrm{C}$. Washes were performed in the intervals of incubations with $0.1 \%$ Tween-20 PBS solution, $\mathrm{pH}$ 7.2. The reaction was quantified with peroxidase-conjugated goat anti-mouse IgG, IgG1, IgG2a, IgG2b or IgG3 antibodies (Southern Biotechnology Associates Inc.) diluted at 1:5000 and incubated for $1 \mathrm{~h}$ at $37^{\circ} \mathrm{C}$. After additional washes, peroxidase activity was assayed with $100 \mu \mathrm{L}$ of Tetramethylbenzidine (TMB) substrates solution (Thermo Scientific Pierce, Pittsburgh PA, USA). Color development was stopped with $50 \mu \mathrm{L}$ of $2 \mathrm{~N} \mathrm{H}_{2} \mathrm{SO}_{4}$. The optical density at $450 \mathrm{~nm}$ was measured with an automated ELISA reader (ELX 800 BIO-TEK Instruments Inc).

\section{Statistical analysis}

Data were analyzed through the one-way ANOVA followed by Bonferroni test. These analyses were performed using the GraphPad Prism software package, with level of significance set at $\mathrm{p}<0.05$.

\section{Results}

\section{CFU recovery from immunocompetent and immunocompromised mice inoculated with LevRad}

No CFU were recovered from the organs and no histopathological changes (data not shown) were observed in the organs obtained from immunocompetent $(\mathrm{Balb} / \mathrm{c})$ and immunocompromised $\left(\mathrm{Balb} / \mathrm{c}^{*}\right)$ mice collected 30 and 90 days after endovenous or intratracheal inoculation with LevRad (Figure 1A and 1B).

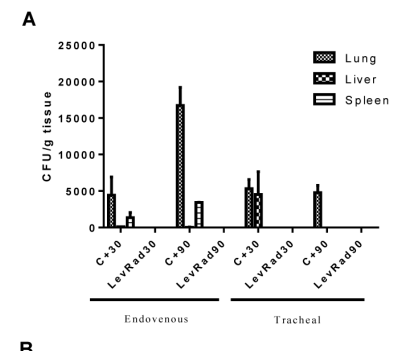

B

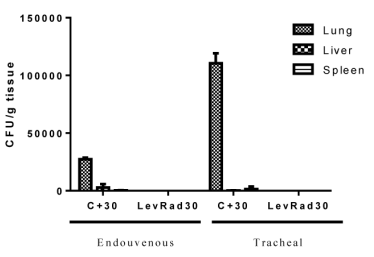

C

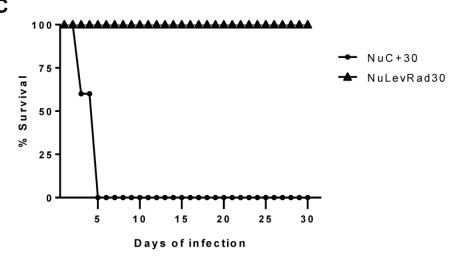

Figure 1: CFU recovered from organs of immunocompetent and immunocompromised mice. (A) Organs CFU estimated 30 (LevRad30) and 90 (LevRad90) days after endovenous or intratracheal inoculation with $3 \times 10^{5}$ viable radioattenuated yeast cells of $P$. brasiliensis (LevRad) in immunocompetent mice. Organs CFU were also estimated $30(\mathrm{C}+30)$ and $90(\mathrm{C}+90)$ days after infection for the same route with $3 \times 10^{5}$ viable virulent yeast cells of P. brasiliensis. (B) CFU estimated 30 (LevRad30) days after endovenous or intratracheal inoculation with LevRad in organs from immunocompromised mice. $\mathrm{CFU}$ were also estimated 30 days $(\mathrm{C}+30)$ after infection with virulent non-irradiated yeast cells of $P$. brasiliensis. (C) Survival curve of Nude mice. Nude mice were infected intratracheally with $3 \times 10^{5}$ yeast cells of virulent $P$. brasiliensis () or LevRad $(\diamond)$. The same experiments were repeated twice with similar results. 
Nude mice infected with the non-irradiated yeast cells $(\mathrm{NuC}+)$ started to die after the first day of infection and $100 \%$ of mortality was achieved at the fifth day. Nude mice inoculated with LevRad remained alive for 30 days (Figure 1C).

These results showed the LevRad inability to produce a progressive infection even in immunocompromised animals.

\section{CFU recovery and histopathological changes from intratracheally infected mice immunized with LevRad associated or not to fluconazole}

To evaluate the therapeutic effect induced by LevRad treated or/and immunized Balb/c mice organs were analyzed 60 and 120 days post infection (30 and 90 days after initiating treatment). A significant reduction of CFU levels in spleen, liver and lung was obtained 60 days after infection in the InMed, InRad and InRadMed groups in relation to $\mathrm{C}+$. The only exception occurred in the InMed group, which did not present a decrease of CFU in the spleen. Moreover, CFU levels decreased significantly in the lung of InRadMed in relation to InMed and InRad. No colonies were recovered from the liver and spleen in this group. Regulation of infection occurred in 120 days in all groups (InMed and InRad, including $\mathrm{C}+$ ), with fungal colonies only being isolated from the lungs. The best result was obtained in the group submitted to chemotherapy using LevRad combined with fluconazole (InRadMed). No colonies (CFU) were obtained from any organs (lung, liver and spleen) in this group (Figure 2).

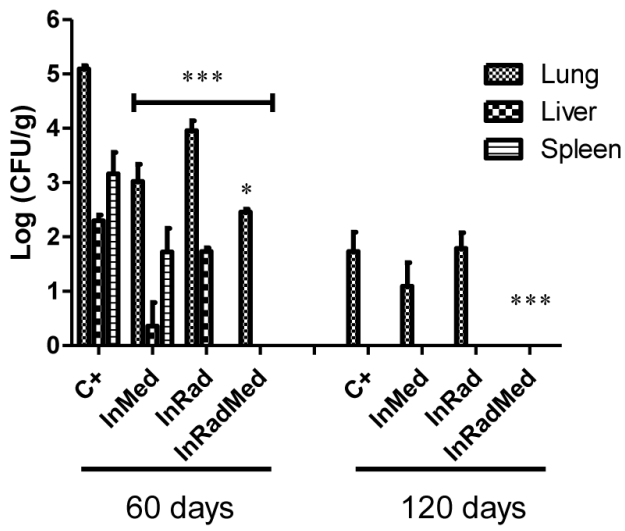

Figure 2: CFU recovery from organs of treated and infected mice. The organs CFU were estimated 60 and 120 days after infection (30 and 90 days after initiating treatment). Mice were infected intratracheally with $3 \times 10^{5}$ yeast cells of $P$. brasiliensis. Negative control (C-) uninfected mice; positive control $(\mathrm{C}+)$ infected mice with virulent non-irradiated yeast cells of $P$. brasiliensis, infected mice treated with fluconazole (InMed); infected mice treated with LevRad (InRad); infected mice treated with LevRad associated with fluconazole (InRadMed). The same experiments were repeated twice with similar results. Data are reported as $\log 10$ (CFU/g) mean+standard deviations in each experimental group $(n=5)$. $* * *$ significant $(\mathrm{p}<0.001)$ difference in relation to positive control. * significant $(\mathrm{p}<0.05)$ difference in relation InMed and InRad.

Furthermore, the histopathological analysis confirmed these results. After 60 days, the lungs of infected animals $(\mathrm{C}+)$ presented extensive tissue destruction with development of intense coalescent multifocal interstitial granulomatous pneumonia (Figure 3A). Neutrophilic linfohistiocytic infiltrate associated with giant cells was observed. There was a large number of intra and extracellular fungal structures with birefringent membrane. Such morphologic feature is characteristic of $P$. brasiliensis (Figure 3B and 3C). The liver showed mild to moderate multifocal granulomas surrounded by fibrous connective tissue constituted by lymphocytes and fungal cells inside (Figure 3D). There was no histhopatological alteration in the spleen (data not shown). A decrease on size of lesion was observed in 120 days in this group. A discrete focal granulomatous lesion was observed in the lung. This lesion was formed by linfohistiocytic infiltrate with giant cells and a few numbers of viable fungal cells (Figure $3 \mathrm{E}$ ). At the same time, the lung obtained from the InRadMed group did not present yeast cells, inflammatory infiltrated or granulomatous lesion (Figure 3F). These results were compared with the results obtained from the uninfected mice (C-). However, the lungs obtained from the InRad and InMed group (analyzed 60 days after infection) presented well organized discrete focal granulomatous lesions with low counting of yeast cells (Figure 3G and 3H). No significant injury was observed in the liver and spleen after 60 days of infection. No histopathological alterations in the liver or the spleen were observed in the studied animals after 120 days (data not shown).

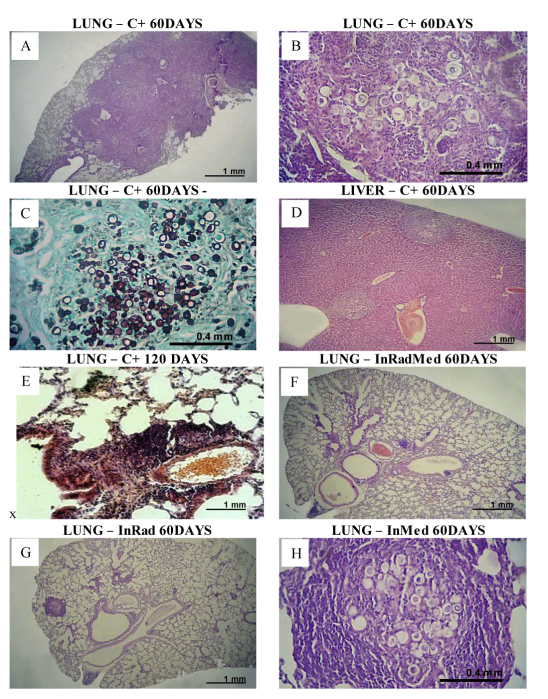

Figure 3: Histopathology of lungs and livers from intratracheally infected mice submitted to the immunization with LevRad associated or not with fluconazole. The extension and distribution of granulomas as well as the fungal burden were observed 60 and 120 days after infection ( 30 and 90 days after initiating treatment). (A) intense coalescent multifocal interstitial granulomatous pneumonia (HE, 40X magnification); (B) (C) intra and extracellular fungal structures with birefringent membrane characteristic of $P$. brasiliensis (HE, 400X magnification); (D) mild to moderate multifocal granulomas surrounded by fibrous connective tissue constituted (HE, 100X magnification); (E) discrete focal granulomatous lesion (HE, 40X magnification); (F) lung free from board fungi, inflammatory infiltrated and granulomatous lesion (HE, 40X magnification); (G) well organized discrete focal granulomatous lesions (HE, 40X magnification); $(\mathrm{H})$ fungal structures inside the granulomas (HE, $400 \mathrm{X}$ magnification). 


\section{iNOS enzyme and cytokines transcript levels in infected mice immunized with LevRad associated or not with fluconazole}

Cytokines (IFN- $\gamma$, IL-10, TNF- $\alpha$, TGF- $\beta$ and IL-4) and iNOS enzyme transcript levels were measured in the lung of infected mice subjected to immunization with LevRad (associated and not associated with fluconazole). One uninfected group was evaluated for basal levels of cytokines (C-), a control group of infected with non-irradiated virulent yeast cells of $P$. brasiliensis $(\mathrm{C}+)$, infected and treated with fluconazole (InMed), infected and treated with LevRad (InRad) and infected and treated with fluconazole associated with LevRad (InRadMed) were also examined.

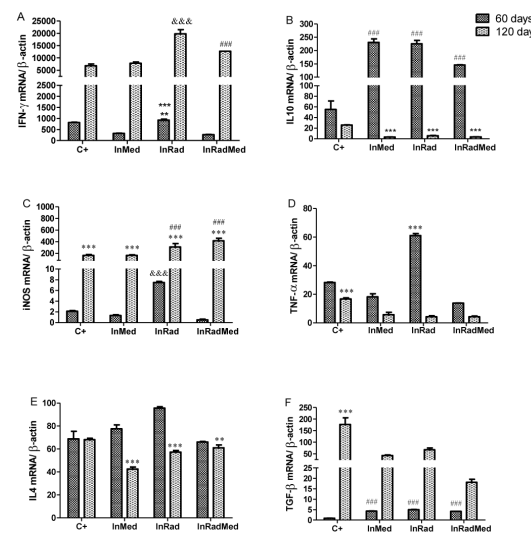

Figure 4: Cytokine transcript levels from mice infected and treated; infected only mice $(\mathrm{C}+)$; infected mice treated with fluconazole (InMed); infected mice treated with LevRad (InRad); infected mice treated with LevRad associated with fluconazole (InRadMed). The same experiments were repeated twice with similar results. Data was reported as mean+standard deviations of relative expression of iNOS enzyme and cytokine in relation to $\beta$-actin from the lungs of 5 animals per group. IFN $-\gamma(\mathrm{A}){ }^{* *}$ significant $(\mathrm{p}<0.05)$ difference related to $\mathrm{C}_{+} ;{ }^{* * *}$ significant $(\mathrm{p}<0.05)$ difference for InMed and InRadMed; \&\&\& significant $(\mathrm{p}<0.05)$ difference related to $\mathrm{C}+$ and InMed; \#\# significant $(\mathrm{p}<0.05)$ difference of InRadMed in relation with $\mathrm{C}+$ and InMed. IL-10 (B) \#\#\# and ${ }^{* * *}$ significant $(\mathrm{p}<0.05)$ difference in relation to $\mathrm{C}+$. iNOS $(\mathrm{C}) \& \& \&$ significant $(\mathrm{p}<0.001)$ difference in relation to $\mathrm{C}+$, InMed and InRadMed; ${ }^{\star * *}$ significant $(p<0.001)$ difference from the first $(60$ days $)$ to the second $(120$ days) data reading; \#\# significant $(\mathrm{p}<0.05)$ difference in relation to $\mathrm{C}+$ and InMed. TNF-alpha $(\mathrm{D}){ }^{* * *}$ significant $(\mathrm{p}<0.05)$ difference to $\mathrm{C}+$, InMed, and InRadMed; \#\#\# significant $(\mathrm{p}<0.05)$ different in $\mathrm{C}+$ in relation to InMed, InRad and InRadMed. IL-4 (E) $* * *$ significant $(\mathrm{p}<0.05)$ difference between InMed and InRad; ** significant $(\mathrm{p}<0.05)$ difference between InRadMed and $\mathrm{C}+$ $(\mathrm{p}<0.05)$. TGF-beta $(\mathrm{F}){ }^{\star * *}$ e \#\#\# significant $(\mathrm{p}<0.05)$ difference between InMed, InRad and InRadMed.

The InRad group presented a significant increase in IFN- $\gamma$ transcript levels compared with the $\mathrm{C}+$, InMed and InRadMed at 60 days post infection. An increase on IFN- $\gamma$ transcript levels was observed at 120 days post infection in all groups analyzed. However, the InRad presented significant expression in relation $\mathrm{C}+$, InMed and InRadMed. The IFN- $\gamma$ expression in InRadMed group also was significant compared to $\mathrm{C}+$ and InMed (Figure $4 \mathrm{~A}$ ). It was possible to observe a significant increase in the IL-10 transcript levels occurring after 60 days of infection in the InMed, InRad and InRadMed groups (in comparison with the $\mathrm{C}+$ group). However, a significant decrease of these levels was observed after 120 days (Figure 4B). A significant iNOS expression occurred in the InRad groups compared to the $\mathrm{C}+$ and InMed and InRadMed after 60 days of infection. All groups submitted to treatment presented an increase on the iNOS enzyme transcript levels from 60 days to 120 days post infection. At the same time, the expression in InRad and InRadMed was significant in relation to $\mathrm{C}+$ and InMed (Figure $4 \mathrm{C}$ ).

TNF-a transcript levels were significantly high in InRad group after 60 days of infection compared to the $\mathrm{C}+$, InMed and InRadMed groups. However, at 120 days, these levels decreased in relation to $\mathrm{C}+$, reaching values similar to the levels observed in the InMed and InRadMed groups (Figure 4D). At the same time, a decrease in the IL-4 transcript levels was also observed in all the tested groups, when compared to the levels registered in C+ (Figure 4E). Low TGF- $\beta$ transcript levels were observed in all groups at 60 days post infection. However, these levels increased at 120 days later. The TGF- $\beta$ transcript levels in $\mathrm{C}+$ were significantly higher than in the other groups (Figure $4 \mathrm{~F})$.

\section{Antibody profile in infected mice immunized with LevRad associated or not to fluconazole}

Serum was collected from treated mice for evaluation of specific responses to Mexo antigen by ELISA. After two rounds of vaccination, significant levels of anti-mexo IgG were detected in the sera of infected mice immunized with LevRad, treated and not treated with fluconazole. The animals infected with $P$. brasiliensis $(\mathrm{C}+)$ did not present significant anti-Mexo antibody levels. The same result was observed in the uninfected group (C-) (Figure 5). Serum of InRad groups had greater specific response than InMed group.

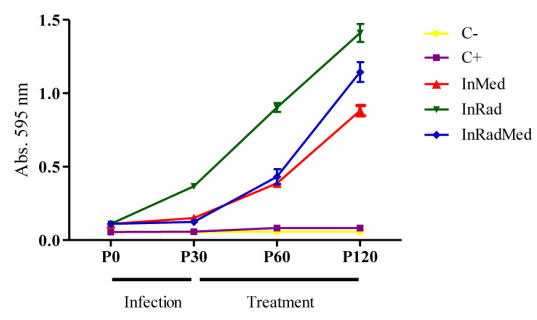

Figure 5: IgG production in serum from infected mice immunized with LevRad associated or not to fluconazole. Antibody responses against Mexo were determined just before (P0), as well as at 30 (P30), 60 (P60) and 120 (P120) days after infection by ELISA. Negative control (C-) uninfected mice; positive control $(\mathrm{C}+)$ infected mice with virulent non-irradiated yeast cells of $P$. brasiliensis; infected mice treated with fluconazole (InMed); infected mice treated with LevRad (InRad); infected mice treated with LevRad associated with fluconazole (InRadMed). The same experiments were repeated twice with similar results. Data were reported as mean + standard deviations of optical density $(450 \mathrm{~nm})$ at $1: 100$ serum dilution in each experimental group $(n=5)$.

Production of anti-Mexo IgG1 isotype was verified after 60 days of infection in the sera of all animals (InMed, InRad, InRadMed and C+). This production was significant when compared to the data obtained from the C-, as well as to the other isotypes (IgG2a, IgG2b and IgG3). 
However, the IgG1 levels did not present a significant difference in relation with the levels of IgG2a and IgG2b in the InRad group, as well as with the levels of IgG2b in the InRadMed group (Figure 6A). At 120 days, no alterations in the $\operatorname{IgG} 1$ levels were observed in comparison with the levels observed 60 days post infection. However, a significant increase on the IgG2a levels was observed in InMed, InRadMed and C + in comparison with C-. This significant increase was also observed for IgG2b in InMed and C+ compared to C- (Figure 6B).

\section{Discussion}

The incidence of diseases caused by pathogenic and opportunistic fungi has been increasing in the past years. The development of new immunological tools to integrate or replace non-effective and lesseffective therapies is becoming more urgent nowadays.

The treatment of PCM is based on the prescription of sulfonamides, polyenes, (amphotericin B) and azoles derivates. However, this treatment is extremely dependent on the drugs' availability and infection severity. PCM requires a long-term treatment and it is limited by toxicity of substances being used and their high cost. Moreover, resistant strains have already been reported $[3,6,7,28]$. It is important to highlight that the use of drugs does not guarantee the complete elimination of the fungus, which may result on reactivation of quiescent foci [5].

There are some reports describing the role of immunogenic antigens on the induction of immune responses to fungal infections, particularly PCM. Studies with yeast cells of $P$. brasiliensis, attenuated by gamma irradiation (LevRad), have been providing promising results. These yeast cells may promote a higher protection when used as a preventive vaccine, against PCM $[18,19]$. There are several examples of highly effective vaccines derived from live attenuated infectious agents (mainly viruses), such as, polio, measles, mumps, rubella, varicella, influenza and rotavirus [29]. For bacteria, the live attenuated Bacille Calmette-Guérin (BCG) vaccine for tuberculosis, is widely used and remained the gold standard despite efforts for the development of other vaccine formulations for this disease [30]. However, reports of vaccines preventing medically important fungal infections in humans are scarce. The only known report is related to formaldehyde-killed Coccidioides immitis spherules, which were tested against coccidioidomycosis [31]. However, the use of this vaccine was not possible, since wrong dosages caused toxic manifestations [32]. A vaccine based on attenuated fungi against ringworm caused by Trichophyton verrucosum has been successfully used in veterinary medicine [33]. A recombinant attenuated strain of Blatomyces dermatitidis has been promising as a potential vaccine against blastomycosis experimental [34,35]. Currently, the safety, tolerability and immunogenicity of this live-attenuated vaccine have been tested in dogs [36].

The high complexity of eukaryotic systems, associated with the high degree of variability within the $P$. brasiliensis group, may pose limitations to the success of vaccines composed by single antigens. This limitation is mainly due to the fact that only few fungi have a single immunodominant epitope possible to be targeted. Some vaccines may only reach considerable effectiveness through the combination of defined antigens promoting a coordinated interaction of many constituents involved in the host's immune response. In this context, the LevRad therapy could be a promising candidate against PCM or an experimental model for the development of new approaches concerning the prevention or treatment of other important fungal infections. It is usual that the living agent induces strong, broad response involving multiple arms of the immune response, which provides natural immunity to disease [6] without the risk of a progressive infection. Although, it is important that the mechanisms which promote the attenuation of fungi are stable.

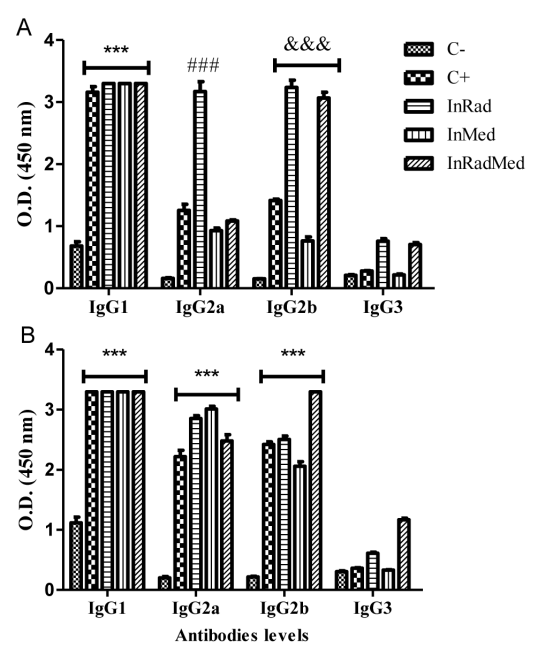

Figure 6: IgG isotypes production against Mexo in serum from infected mice immunized with LevRad associated or not to fluconazole. Antibody responses against Mexo were determined 60 (A) and 120 (B) days after infection (30 and 90 days after initiating treatment) by ELISA. Negative control (C-) uninfected mice; positive control $(\mathrm{C}+)$ infected mice with virulent non-irradiated yeast cells of $P$. brasiliensis, infected mice treated with fluconazole (InMed); infected mice treated with LevRad (InRad); infected mice treated with LevRad associated to fluconazole (InRadMed). The same experiments were repeated twice with similar results. Data were reported as mean + standard deviations of optical density (450 $\mathrm{nm})$ at 1:100 serum dilution in each experimental group $(\mathrm{n}=5)$. ${ }^{* *}$ significant $(\mathrm{p}<0.001)$ difference in relation to $\mathrm{C}$ - and the other isotypes (IgG2a, IgG2b and IgG3); \#\#\# significant $(\mathrm{p}<0.001)$ difference in relation to $\mathrm{C}-, \mathrm{C}+$, InMed and InRadMed; \&\&\& Significant $(\mathrm{p}<0.001)$ difference in relation to $\mathrm{C}$ - and $\mathrm{C}+$ and InMed.

Previous studies have already reported that radioattenuated fungi suffer an extensive DNA fragmentation, beyond cell repairment mechanisms. This leads to an irreversible loss of yeast reproductive ability and virulence $[16,19,33]$. The inability of LevRad to cause infection was confirmed in this study using immunocompromised $\left(\mathrm{BALB} / \mathrm{c}^{\star}\right)$ and immunocompetent $(\mathrm{BALB} / \mathrm{c})$ mice. No $\mathrm{CFU}$ or histopathological alterations were observed, 30 and 90 days after inoculation with LevRad, in the organs of the studied animals. Athymic mice (Nude) achieved $100 \%$ of mortality at the fifth day of experiment, while Nude mice inoculated with LevRad remained alive for 30 days.

Combined therapy of immunotherapeutic and antifungal agents has been tested as an adjuvant in potentializing the chemotherapy. This is an attempt to reduce toxicity of conventional drugs, the period of treatment and to prevent relapses of the disease [5]. Here we reported, for the first time, the immunotherapeutic potential of radioattenuated fungi associated with fluconazole in the treatment of PCM. 
The immunization of infected BALB/c mice with LevRad associated with fluconazole (InRadMed) elicited a great therapeutic effect against highly infective yeast strains of $P$. brasiliensis. A reduction of CFU in the lungs from the InRadMed group in relation to animals only infected $(\mathrm{C}+)$ was already observed 60 days after infection. There was no fungal dissemination to the liver or the spleen. No fungal colonies were recovered from any organs (lung, liver and spleen) at 120 days post infection. It is safe to report that the combined administration of LevRad and fluconazole was capable of preventing relapse effects in this study. This was also confirmed by the histopathological analysis. Such analysis showed that the organs (lung, liver and spleen) preserved lung parenchyma as well as did not present yeast cells or granulomatous lesions. It is already well documented that resistance to $P$. brasiliensis infection is determined mainly by the host's ability to restrict fungal dissemination rather than the control of fungal growth in the primary infection site [37]. Moreover, it is important to consider the elimination of possible fungal quiescent focus as demonstrated 120 days after infection. The fungal cells may establish a dormant state and spontaneously reactivate. This reactivation may also occur when the host's immune system is impaired.

At the same time, the groups of infected animals immunized with LevRad (InRad) and treated with fluconazole (InMed) presented a significant reduction in the number of $\mathrm{CFU}$, when compared to $\mathrm{C}+$. This reduction was not observed between the InRad and the InMed groups though. The lungs obtained from the InMed and InRad groups presented organized well discrete focal neutrofilic and linfohistiocytic granulomatous lesions with a few number of yeast cells. Immunization of infected animals with LevRad was effective, although at first it did not present benefits when compared with fluconazole treatment. However, it is important to highlight that the infected animals were immunized only twice with LevRad (no adjuvants), with a fortnight interval between events. On the other hand, fluconazole was administered for 30 days with no interruptions. Besides, animals from the InRad group were first evaluated 15 days after the medication was suspended whereas the animals from the InMed were evaluated immediately after the end of treatment.

The infected mice immunized with LevRad presented early expression (60 days after infection) of high TNF- $\alpha$ transcript levels in relation to the other groups (C+, InMed and InRadMed) which were not enough to ensure the fungi elimination. Moreover, it is plausible to believe that IL-4 may has contributed to the colonization and reproduction of the fungus in the lung, as well as its dissemination to the other organs (liver and spleen) as observed at 60 days post infection in InRad, InMed and C+. In contrast, we observed at 120 days after infection high transcript levels of IFN- $\gamma$ and iNOs enzyme especially in the InRad and InRadMed groups, with low IL-10 and IL-4 levels. This observation occurred concomitant with a complete resolution of the disease in InRadMed (120 days after infection). A significant decrease in the number of CFU and histopathological lesions was also observed in InMed and InRad. It is well known that IFN- $\gamma$ plays an important role in resistance to $P$. brasiliensis infection due to increase in the clearance of fungal cells, its regulation by cellmediated immune responses and its regulatory effects on specific humoral immune responses [38]. NO may be considered a potent microbicide factor and its secretion is related with the fungus elimination and consequent host protection [39-41]. Regarding TGF$\beta$, the high expression verified at 120 days post infection may be due to the regulation of inflammatory response induced by proinflamatory cytokines $[7,42,43]$.
In the present study, we also evaluated the specific antibody levels. High levels of IgG in the InMed, InRad and InRadMed groups were observed due to a response to the presence of the exoantigen of $P$. brasiliensis (Mexo). This suggests that this antigen may also contain $\mathrm{B}$ cell epitopes. A significant production of $\operatorname{IgG1}$ was observed in all groups (C+, InMed, InRad and InRadMed) from 60 to 120 days of infection. High production of IgG2a, IgG2b and IgG3 in the InRad group was registered, as well as of IgG2b and IgG3 in the InRadMed group, after 60 days of infection. At 120 days, IgG2a and IgG2b levels were high in the InRad, InMed, InRadMed and C+ groups. However, IgG2a titers were higher in infected mice (immunized and treated) than in the $\mathrm{C}+$ group. Protection against PCM has been attributed to a vigorous cellular immune response especially associated with Th1, whereas the high IgG levels and depressed cellular immune response was associated with progressive disease. Recently, however, some evidences have demonstrated the antibody-mediated protection against pathogenic fungi, such as antibodies to Cryptococcus neoformans polysaccharides or to Candida albicans cell wall components [44-46] as well as anti-gp70 Mabs [47] and some antigp43 MAbs [48] in experimental PCM. Besides, some IgG isotypes are associated with a Th1 response profile as well as works effectively on opsonization and activation of the complement system. IFN- $\gamma$ is considered the major inducer of a switch to IgG2a secretion, whereas IL- 4 has been associated with isotypes switching to IgG1 and TGF- $\beta$ functions as an important Ig2b switch factor $[11,49]$.

The high expression of IFN- $\gamma$, iNOS and TGF- $\beta$, and low expression of IL-4 and IL-10 (observed 120 days after infection) associated with high production of IgG2a and IgG2b, as well as, the low fungal load, the preserved tissues and low mortality rates suggest the predominant establishment of Th1-type immune response observed in InRadMed.

Finally, the results obtained in the present study provide important information concerning fungal immunotherapy demonstrating, by using yeast attenuated cells, that it is achievable for PCM. It was observed an additive effect of LevRad immunization to chemotherapy in PCM experimental that could be relevant mainly for studies dealing with drug resistance.

\section{Acknowledgements}

This research was supported by Fundação de Amparo a Pesquisa do Estado de Minas Gerais (FAPEMIG), (CBB-APQ 00967-09) and Conselho Nacional de Desenvolvimento Científico e Tecnológico (CNPq).

\section{References}

1. Restrepo A (1985) The ecology of Paracoccidioides brasiliensis: a puzzle still unsolved. Sabouraudia 23: 323-334.

2. Shikanai-Yasuda MA1, Telles Filho Fde Q, Mendes RP, Colombo AL, Moretti ML (2006) Guidelines in paracoccidioidomycosis. Rev Soc Bras Med Trop 39: 297-310.

3. Visbal G, San-Blas G, Murgich J, Franco H (2005) Paracoccidioides brasiliensis, paracoccidioidomycosis, and antifungal antibiotics. Curr Drug Targets Infect Disord 5: 211-226.

4. San-Blas G, Niño-Vega G (2008) Paracoccidioides brasiliensis: chemical and molecular tools for research on cell walls, antifungals, diagnosis, taxonomy. Mycopathologia 165: 183-195.

5. Travassos LR, Rodrigues EG, Iwai LK, Taborda CP (2008) Attempts at a peptide vaccine against paracoccidioidomycosis, adjuvant to chemotherap. Mycopathologia 165: 341-352. 
6. Cutler JE, Deepe GS Jr, Klein BS (2007) Advances in combating fungal diseases: vaccines on the threshold. Nat Rev Microbiol 5: 13-28.

7. Cassone A (2008) Fungal vaccines: real progress from real challenges. Lancet Infect Dis 8: 114-124.

8. Marques AF, da Silva MB, Juliano MA, Travassos LR, Taborda CP (2006) Peptide immunization as an adjuvant to chemotherapy in mice challenged intratracheally with virulent yeast cells of Paracoccidioides brasiliensis. Antimicrob Agents Chemother 50: 2814-2819.

9. Marques AF, Silva MB, Juliano MA, Munhoz JE, Travassos LR, et al. (2008) Additive effect of P10 immunization and chemotherapy in anergic mice challenged intratracheally with virulent yeasts of Paracoccidioides brasiliensis. Microbes Infect 10: 1251-1258.

10. Diniz SN, Reis BS, Goes TS, Zouain CS, Leite MF, et al. (2004) Protective immunity induced in mice by F0 and FII antigens purified from Paracoccidioides brasiliensis. Vaccine 22: 485-492.

11. Reis BS, Fernandes VC, Martins EM, Serakides R, Goes AM (2008) Protective immunity induced by $\mathrm{rPb} 27$ of Paracoccidioides brasiliensis. Vaccine 26: 5461-5469.

12. Fernandes VC, Martins EM, Boeloni JN, Coitinho JB, Serakides R, et al. (2011) Additive effect of $\mathrm{rPb} 27$ immunization and chemotherapy in experimental paracoccidioidomycosis. PLoS One 6: e17885.

13. Ribeiro AM, Bocca AL, Amaral AC, Faccioli LH, Galetti FC, et al. (2009) DNAhsp65 vaccination induces protection in mice against Paracoccidioides brasiliensis infection. Vaccine 27: 606-613.

14. Ribeiro AM, Bocca AL, Amaral AC, Souza AC, Faccioli LH, et al. (2010) HSP65 DNA as therapeutic strategy to treat experimental paracoccidioidomycosis. Vaccine 28: 1528-1534.

15. Coltri KC, Oliveira LL, Pinzan CF, Vendruscolo PE, Martinez R, et al. (2008) Therapeutic Administration of KM+ Lectin Protects Mice Against Paracoccidioides brasiliensis Infection via Interleukin-12 Production in a Toll-Like Receptor 2-Dependent Mechanism. Am J Pathol 2: 423-432.

16. Demicheli MC, Reis BS, Goes AM, de Andrade AS (2006) Paracoccidioides brasiliensis: attenuation of yeast cells by gamma irradiation. Mycoses 49: 184-189.

17. do Nascimento Martins EM, Reis BS, Fernandes VC, Costa MM, Goes AM, et al. (2007) Immunization with radioattenuated yeast cells of Paracoccidioides brasiliensis induces a long lasting protection in $\mathrm{BALB} / \mathrm{c}$ mice. Vaccine 25: 7893-7899.

18. do Nascimento Martins EM, Reis BS, de Resende MA, de Andrade AS, Goes AM (2009) Mice immunization with radioattenuated yeast cells of Paracoccidiodes brasiliensis: influence of the number of immunizations. Mycopathologia 168: 51-58.

19. Fernandes VC, Martins EMN, Boeloni JN, Coitinho JB, Serakides R, et al. (2011) The combined use of Paracoccidioides brasiliensis $\mathrm{Pb} 40$ and $\mathrm{Pb} 27$ recombinant proteins enhances chemotherapy effects in experimental paracoccidioidomycosis, Microbes Infect 13: 1062-1072.

20. Rittner GM, Muñoz JE, Marques AF, Nosanchuk JD, Taborda CP, et al. (2012) Therapeutic DNA vaccine encoding peptide P10 against experimental paracoccidioidomycosis. PLoS Negl Trop Dis 6: e1519.

21. de Amorin J, Magalhaes A, Munoz JE, Rittner GM, Nosanchuk JD, et al. (2013) DNA vaccine encoding peptide P10 against experimental paracoccidioidomycosis induces long-term protection in presence of regulatory T cells. Microbes Infect 15: 181-191.

22. Ribeiro AM, Souza AC, Amaral AC, Vasconcelos NM, Jeronimo MS, et al. (2013) Nanobiotechnological approaches to delivery of DNA vaccine against fungal infection. J Biomed Nanotechnol 9: 221-230.

23. Morschhauser J (2012) Regulation of multidrug resistance in pathogenic fungi, Fungal Genet Biol 159: 1126-1132.

24. Diniz SN, Cisalpino PS, Koury MC, Andrade GM, Nogueira MG, et al. (1999) In vitro human immune reactivity of fast protein liquid chromatography fractionated Paracoccidioides brasiliensis soluble antigens. Microbes Infect 1: 353-360.

25. Brummer E, Castaneda E, Restrepo A (1993) Paracoccidioidomycosis: an update. Clin Microbiol Rev 6: 89-117.
26. Giulietti A, Overbergh L, Valckx D, Decallonne B, Bouillon R, et al. (2001) An overview of real-time quantitative PCR: applications to quantify cytokine gene expression. Methods 25: 386-401.

27. Reis BS, Bozzi A, Prado FL, Pereira MC, Ferreira FE, et al. (2005) Membrane and extracellular antigens of Paracoccidioides brasiliensis (Mexo): identification of a $28-\mathrm{kDa}$ protein suitable for immunodiagnosis of paracoccidioidomycosis. J Immunol Methods 307: 118-126.

28. Dan JM, Levitz SM (2006) Prospects for development of vaccines against fungal diseases. Drug Resist Updat 9: 105-110.

29. Hohl TM, Van Epps HL, Rivera A, Morgan LA, Chen PL, et al. (2005) Aspergillus fumigatus triggers inflammatory responses by stage-specific beta-glucan display. PLoS Pathog 1: e30.

30. Mark Doherty T (2004) New vaccines against tuberculosis. Trop Med Int Health 9: 818-826.

31. Pappagianis D (1993) Evaluation of the protective efficacy of the killed Coccidioides immitis spherule vaccine in humans. The Valley Fever Vaccine Study Group. Am Rev Respir Dis 148: 656-660.

32. Deepe GS Jr (2004) Preventative and therapeutic vaccines for fungal infections: from concept to implementation. Expert Rev Vaccines 3: 701-709.

33. Gudding R, Naess B (1986) Vaccination of cattle against ringworm caused by Trichophyton verrucosum. Am J Vet Res 47: 2415-2417.

34. Wuthrich M, Filutowicz HI, Warner T, Deep GS, Klein BS (2003) Vaccine immunity to pathogenic fungi overcomes the requirement for $\mathrm{CD} 4+\mathrm{T}$ help in exogenous antigen presentation to CD8+T cells: implications for vaccine development in immune-deficient hosts. J Exp Med 197: 1405-1416.

35. Wuthrich M, Filutowicz HI, Klein BS (2000) Mutation of the WI-1 gene yields an attenuated blastomyces dermatitidis strain that induces host resistance. J Clin Invest 106: 1381-1389.

36. Wuthrich M, Krajaejun T, Shearn-Bochsler V, Bass C, Hanna I, et al. (2011) Safety, Tolerability, and Immunogenicity of a Recombinant, Genetically Engineered, Live-Attenuated Vaccine against Canine Blastomycosis. Clin vaccine immunol 18: 783-789.

37. Cano LE, Singer-Vermes LM, Vaz CA, Russo M, Calich VL (2005) Pulmonary paracoccidioidomycosis in resistant and susceptible mice: relationship among progression of infection, bronchoalveolar cell activation, cellular immune response, and specific isotype patterns. Infect Immun 63: 1777-1783.

38. Cano LE, Kashino SS, Arruda C, André D, Xidieh CF, et al. (1998) Protective role of gamma interferon in experimental pulmonary paracoccidioidomycosis. Infect Immun 66: 800-806.

39. Souto JT, Figueiredo F, Furlanetto A, Pfeffer K, Rossi MA, et al. (2000) Interferon-gamma and tumor necrosis factor-alpha determine resistance to Paracoccidioides brasiliensis. Am J Pathol 156: 1811-1820.

40. Gonzalez A, de Gregori W, Velez D, Restrepo A, Cano LE (2000) Nitric oxide participation in the fungicidal mechanism of gamma interferonactivated murine macrophages against Paracoccidioides brasiliensis conidia. Infect Immun 68: 2546-2552.

41. Tsunawaki S, Sporn M, Ding A, Nathan C (1988) Deactivation of macrophages by transforming growth factor-beta. Nature 334: 260-262.

42. Fortes MR, Miot HA, Kurokawa CS, Marques ME, Marques SA (2011) Immunology of paracoccidioidomycosis. An Bras Dermatol 86: 516-524.

43. Parise-Fortes MR, Marques SA, Soares AM, Kurokawa CS, Marques ME (2006) Cytokines released from blood monocytes and expressed in mucocutaneous lesions of patients with paracoccidioidomycosis evaluated before and during trimethoprim-sulfamethoxazole treatment. Br J Dermatol 154: 643-650.

44. Cutler JE (2005) Defining criteria for anti-mannan antibodies to protect against candidiasis. Curr Mol Med 5: 383-392.

45. Han Y, Morrison RP, Cutler JE (1998) A vaccine and monoclonal antibodies that enhance mouse resistance to Candida albicans vaginal infection. Infect Immun 66: 5771-5776. 
Citation: Nascimento Martins EMD, Fernandes VC, Morais EA, Boeloni JN, Resende AD, et al. (2014) Evaluation of the Therapeutic Effect of Radioattenuated Yeast Cells in Experimental Paracoccidioidomycosis. J Vaccines Vaccin 5: 248. doi:10.4172/2157-7560.1000248

Page 9 of 9

46. de Mattos Grosso D, de Almeida SR, Mariano M, Lopes JD (2003) Characterization of gp70 and anti-gp70 monoclonal antibodies in Paracoccidioides brasiliensis pathogenesis. Infect Immun 71: 6534-6542.

47. Casadevall A (1998) Antibody-mediated protection against intracellular pathogens. Trends Microbiol 6: 102-107.

48. Buissa-Filho R, Puccia R, Marques AF, Pinto FA, Munoz JE, et al. (2008) The monoclonal antibody against the major diagnostic antigen of
Paracoccidioides brasiliensis mediates immune protection in infected $\mathrm{BALB} / \mathrm{c}$ mice challenged intratracheally with the fungus. Infect Immun 76: 3321-3328.

49. Deenick EK, Hasbold J, Hodgkin PD (1999) Switching to IgG3, IgG2b, and IgA is division linked and independent, revealing a stochastic framework for describing differentiation. J Immunol 163: 4707-4714. 